\title{
A higher CD4/CD8 ratio correlates with an ultralow cell-associated HIV-1 DNA level in chronically infected patients on antiretroviral therapy: a case control study
}

Yongsong Yue ${ }^{1}$, Nidan Wang ${ }^{1}$, Yang Han ${ }^{1}$, Ting Zhu' ${ }^{1}$, Jing Xie ${ }^{1,2,3}$, Zhifeng Qiu' ${ }^{1}$ Xiaojing Song ${ }^{1}$, Yanling Li', Jean-Pierre Routy ${ }^{4}$, Jianhua Wang ${ }^{5,6^{*}}$ and Taisheng $\mathrm{Li}^{1,2,3^{*}}$

\begin{abstract}
Background: The HIV-1 DNA reservoir is an important marker that reflects viro-immunological status and can be affected by multiple viral or cellular factors. Determining the potential factors associated with the size of the HIV-1 DNA reservoir benefits the surveillance of disease progression and antiretroviral treatments.

Methods: We conducted a case control study to explore the factors that may affect the level of HIV-1 DNA. The level of HIV-1 total DNA in peripheral blood at 5 time points was quantified by quantitative PCR. Chronically HIV-1infected patients whose cell-associated HIV-1 DNA levels were below the detection limit after receiving antiretroviral therapy (ART) for 96 weeks were identified (group 1), and patients who still had detectable levels of cell-associated HIV1 DNA after ATR treatment were used as the control (group 2).

Results: Twenty-one patients with ultralow levels of cell-associated HIV-1 DNA $\left[<20\right.$ copies $/ 10^{6}$ peripheral blood mononuclear cells (PBMCs)] presented with a lower CD8 ${ }^{+}$T-cell count (average: $511 \pm 191$ versus $715 \pm 256$ cells/ $\mu \mathrm{L}, p=0.013$ ) and a higher CD4/CD8 ratio (average: $1.04 \pm 0.37$ versus $0.72 \pm 0.32$, respectively, $p=0.002$ ) at week 96. In the multivariate analysis, patients with a higher CD4/CD8 ratio at week 96 were more likely to have levels of HIV-1 DNA below the detection limit (per 0.1 increase, $\mathrm{OR}=1.29,95 \% \mathrm{Cl}, 1.05-1.59, p=0.017$ ).

Conclusion: After matching baseline HIV-1 DNA levels, a higher CD4/CD8 ratio at week 96 was the only factor associated with an ultralow level of HIV-1 DNA. The CD4/CD8 ratio can be used as an easy biomarker to help monitor patients on ART who will be selected to participate in eradication studies.
\end{abstract}

Keywords: HIV-1, DNA reservoir, Antiretroviral therapy, CD8 ${ }^{+}$T-lymphocytes, CD4/CD8 ratio

\section{Background}

HIV-1 persistence in infected memory $\mathrm{CD}^{+}{ }^{+} \mathrm{T}$ cells represents a major obstacle for eradication even after longterm antiretroviral treatment $[1,2]$. Establishment of HIV-1 DNA reservoirs occurs days after HIV-1 infection and exists in different tissues, including lymph nodes and preferentially in memory $\mathrm{CD} 4^{+} \mathrm{T}$ cells [3-6]. The

\footnotetext{
* Correspondence: jh_wang@sibs.ac.cn; litsh@263.net

${ }^{5}$ CAS Key Laboratory of Molecular Virology and Immunology, Institute

Pasteur of Shanghai, Chinese Academy of Sciences, Shanghai 200031, China

${ }^{1}$ Department of Infectious Diseases, Peking Union Medical College Hospital,

Chinese Academy of Medical Sciences \& Peking Union Medical College,

Beijing 100730, China

Full list of author information is available at the end of the article
}

size of the HIV-1 DNA reservoir measured before antiretroviral therapy (ART) initiation is an important marker that reflects the viro-immunological status, is independently correlated with disease progression, and can be used to predict the timing of viral rebound after treatment interruption [7-10].

The level of peripheral blood mononuclear cell (PBMC)associated HIV-1 DNA can be affected by multiple factors, including the plasma viral load, the peripheral $\mathrm{CD}_{4}^{+} \mathrm{T}$ lymphocyte count, the timing of ART initiation and the duration of ART treatment as well as the immune activation status [11-17]. Early and prolonged treatment, in concert with optimal viral control and high $\mathrm{CD} 4^{+} \mathrm{T}$-cell count, 
is associated with a lower level of HIV-1 DNA [18]. In rare cases, post-treatment controllers also reduce the level of HIV-1 DNA, as in the VISCONTI study [19].

Determining the potential viral or cellular factors that are associated with the size of the HIV-1 DNA reservoir benefits the surveillance of disease progression and antiretroviral treatments. In the current case control study, we identified 21 patients with chronic HIV-1 infection who had undetectable cell-associated HIV-1 DNA levels after 2 years of ART treatment. The 48 other patients, who still had detectable cell-associated HIV-1 DNA levels after ATR treatment, were used as the control. We focused on analyzing other factors associated with below-detection-level DNA by matching baseline HIV-1 DNA levels between the two groups and found that the $\mathrm{CD} 4 / \mathrm{CD} 8$ ratio at week 96 was the only factor associated with an ultralow HIV-1 DNA level.

\section{Methods Subjects}

Sixty-nine patients in this study were selected from two previous adult HIV-1 treatment cohorts [20, 21]: cohort 1, recruited between 2008 and 2010, consisting of patients with a CD4 $4^{+} \mathrm{T}$-cell count $<350$ cells $/ \mu \mathrm{L}$ and receiving an ART regimen of zidovudine/stavudine + lamividine + nevirapine $(\mathrm{AZT} / \mathrm{d} 4 \mathrm{~T}+3 \mathrm{TC}+\mathrm{NVP})$; and cohort 4 , recruited between 2012 and 2014, comprising patients with a CD4 ${ }^{+}$ T-cell count $<500$ cells $/ \mu \mathrm{L}$ and receiving an ART regimen of tenofovir + lamividine + efavirenz (TDF + 3TC + EFV). Peripheral blood was collected for T-cell enumeration and plasma viral load detection, and the remainder from each visit was stored at $-80{ }^{\circ} \mathrm{C}$ [pre-ART (week 0 ), 3 months (week 12), 6 months (week 24), 1 year (week 48), and 2 years after initiation ART (week 96)]. Demographic characteristics, $\mathrm{CD} 4^{+}$and $\mathrm{CD} 8^{+}$T-cell counts, HIV-1 viral subtype, and plasma HIV-1 RNA viral loads were extracted from the database.

HIV-1 DNA quantification was performed in 868 patients with available samples from these two cohorts. Among them, 651 patients achieved viral suppression (viral load $<50$ copies $/ \mathrm{mL}$ ) within 48 weeks of ART. Further, 21 patients with ultralow HIV-1 DNA levels $(<20$ copies $/ 10^{6}$ PBMCs) at week 96 and strict viral suppression (HIV-1 RNA maintained $<50$ copies $/ \mathrm{mL}$ after 48 weeks of ART without viral blip) were selected in group 1. To analyze other factors associated with ultralow HIV-1 DNA levels, patients with strict viral suppression but detectable HIV-1 DNA at week 96 were selected for the control group (group 2) by matching baseline HIV-1 DNA levels. According to the proportion of 1:2 (number of patients in group 1: group 2), 42 patients were tended to be randomly chosen from those with baseline HIV-1 DNA $<2.4 \log$ copies $/ 10^{6}$ PBMCs
(75 quantile of HIV-1 DNA in group 1). In fact, only 48 patients met that criterion, and the level of baseline HIV-1 DNA was balanced with group 1 . Hence, those 48 patients were assigned to group 2 .

All 69 patients were treatment-naïve when enrolled, achieved and maintained viral suppression ( $<50$ copies/ $\mathrm{mL}$ ) without blip after 48 weeks of ART and were followed for 96 weeks. Among them, 45 (65\%) patients achieved viral suppression at week 12, 18 (26\%) patients at week 24, and 6 (9\%) patients at week 48 on ART. During follow-up (96 weeks), their viral loads were always less than 50 copies/mL without blip.

\section{HIV DNA quantification}

Total cellular DNA was extracted from $200 \mu \mathrm{L}$ peripheral blood using Qiagen QIAsymphony DNA Mini Kits (QIAGEN, Valencia, CA), and HIV-1 DNA in the peripheral blood (mainly the white blood cells, WBCs) was amplified and quantified for LTR gene using a fluorescence-based, real-time SUPBIO HIV Quantitative Detection Kit (SUP$\mathrm{BIO}$, Guangzhou, China). The quantification range of this assay was $20-5 \times 10^{6}$ copies $/ 10^{6}$ WBCs. The amount of HIV-1 DNA per $10^{6}$ PBMCs was calculated.

\section{Statistical analysis}

Differences in continuous and categorical variables between the two groups were assessed using standard nonparametric tests and the chi-squared test, respectively. Undetectable HIV-1 RNA and DNA results were given the value of the detection limit (20 copies/mL for HIV-1 RNA and 20 copies $/ 10^{6}$ PBMCs for HIV-1 DNA). Univariate and multivariate logistic regression were employed to identify predictors of below-detection-level total HIV-1 DNA. Factors with a $p$ value $<0.10$ in the univariate logistic regression analysis were included in a multivariate logistic regression model, and all factors were subjected to backward-stepwise likelihood ratio (LR) regression with $p<0.20$ as the exclusion criterion. Statistical analysis was performed using SPSS 22.0 (IBM Corporation, Armonk, New York, USA) and GraphPad Prism 6.0 (GraphPad Software, Inc. La Jolla, CA, USA). A $p$ value $<0.05$ was considered statistically significant.

\section{Results}

\section{Baseline characteristics of the patients}

In the case control study, the 69 patients with successful treatment were selected from the cohorts and were stratified into two groups according to the level of cellassociated HIV-1 DNA after 96 weeks of ART. In group 1 , the 21 patients had undetectable HIV-1 DNA $(<20$ copies $/ 10^{6}$ PBMCs) after 96 weeks of ART, and in group 2 (control), the 48 patients still had detectable cell-associated HIV-1 DNA after ATR treatment [median log copies $/ 10^{6}$ PBMCs, 1.91 ; inter-quartile range 
(IQR), 1.6-2.4, $p<0.001]$. The other characteristics of the two groups, including sex, age, HIV-1 subtype, the antiretroviral regimens, pre-ART HIV-1 DNA and plasma RNA, pre-ART $\mathrm{CD}^{+}$and $\mathrm{CD} 8^{+}$T-cell counts, and nadir $\mathrm{CD}^{+}$T-cell count, were all matched (Table 1).

The information of these 69 patients is summarized in Table 1. A total of $62.3 \%$ of patients were male. The median age was 33 years (IQR, 27-39). Among them, 21 patients were infected with the HIV-1 AE subtype and 19 patients with either the $\mathrm{B}, \mathrm{C}$, or $\mathrm{BC}$ subtype. All patients were diagnosed with HIV-1 and received ART during the chronic phase. The median time from diagnosis to ART was 7.7 months. The baseline virological and immunological characteristics of these patients were as follows: median pre-ART plasma viral load, 4.1 (IQR, 3.6-4.5) $\log$ copies/mL; median CD4 ${ }^{+}$T-cell count, 305 (IQR, 256-385) cells $/ \mu \mathrm{L}$; median nadir $\mathrm{CD}^{+}{ }^{+} \mathrm{T}$-cell count, 292 (IQR, 245-357) cells $/ \mu \mathrm{L}$; median $\mathrm{CD}^{+}$T-cell count, 845 (IQR, 614-1073) cells/ $\mu \mathrm{L}$; median CD4/CD8 ratio, 0.35 (IQR, 0.27-0.51); and median pre-ART HIV total DNA, 2.0 (IQR, 1.7-2.2) log copies $/ 10^{6}$ PBMCs. Two types of antiretroviral regimens were used. Nineteen patients $(27.5 \%)$ received $\mathrm{AZT} / \mathrm{d} 4 \mathrm{~T}+3 \mathrm{TC}+\mathrm{NVP}$, and 50 patients $(72.5 \%)$ received $\mathrm{TDF}+3 \mathrm{TC}+\mathrm{EFV}$.
Temporal changes in the plasma viral load, $\mathrm{CD}^{+}$and CD8 + T-cell counts, CD4/CD8 ratio, and HIV-1 DNA level during ART

These 69 patients showed suppressed HIV-1 RNA production after 48 weeks of ART, and there was no obvious difference in the plasma viral load between the two groups at the evaluation time points (Fig. 1a). A significant difference in the cell-associated HIV-1 DNA level appeared at week 12 after initiating ART ( $p=0.003)$, and the difference persisted at weeks 24 and $96(p=0.029$ and $p<0.001$, respectively, Fig. 1b). Upon ATR treatment, the CD4. T-cell count showed a rapid recovery within 12 weeks, but no significant difference in the $\mathrm{CD} 4^{+} \mathrm{T}$-cell count was observed between the two groups at any evaluated time points (Fig. 1c). Intriguingly, the number of $\mathrm{CD}^{+} \mathrm{T}$ cells in group 1 continued to decrease after week 24, resulting in a significantly lower $\mathrm{CD} 8^{+} \mathrm{T}$-cell count at week 48 ( $p=0.043)$ and week 96 ( $p=0.013$, Fig. 1d). Consequently, a higher CD4/CD8 ratio was observed at these two visits $(p=0.018$ and $p=0.002$, respectively, Fig. 1e).

\section{Higher CD4/CD8 ratio is associated with undetectable HIV-1 DNA at 96 weeks of ART}

To identify which factors were associated with undetectable HIV-1 DNA levels at 96 weeks of ART in group 1, a

Table 1 Characteristics of the overall study population and stratification by HIV-1 DNA level at week 96

\begin{tabular}{|c|c|c|c|c|}
\hline Variables & Total $(N=69)$ & Group $1(N=21)$ & Group $2(N=48)$ & $P$ value \\
\hline Sex & & & & 0.082 \\
\hline Male & $43(62.3 \%)$ & $10(47.6 \%)$ & $33(68.8 \%)$ & \\
\hline Female & $26(37.7 \%)$ & $11(52.4 \%)$ & $15(31.2 \%)$ & \\
\hline Age (years) & $33(27-39)$ & $33(29-41)$ & $33(27-38)$ & 0.396 \\
\hline Time from diagnosis to ART (months) & $7.7(1.1-25.5)$ & $6.0(1.0-16.0)$ & $9.0(1.2-28.0)$ & 0.556 \\
\hline HIV-1 subtype & & & & 0.422 \\
\hline$A E$ & $21(30.4 \%)$ & $5(23.8 \%)$ & $16(33.3 \%)$ & \\
\hline $\mathrm{B} / \mathrm{C} / \mathrm{BC}$ & $19(27.5 \%)$ & $6(28.6 \%)$ & $13(27.1 \%)$ & \\
\hline Not known & $29(42.1 \%)$ & $10(47.6 \%)$ & $19(39.6 \%)$ & \\
\hline ART therapy & & & & 0.332 \\
\hline $\mathrm{AZT} / \mathrm{d} 4 \mathrm{~T}+3 \mathrm{TC}+\mathrm{NVP}$ & $19(27.5 \%)$ & $7(33.3 \%)$ & $12(25.0 \%)$ & \\
\hline $\mathrm{TDF}+3 \mathrm{TC}+\mathrm{EFV}$ & $50(72.5 \%)$ & $14(66.7 \%)$ & $36(75.0 \%)$ & \\
\hline $\begin{array}{l}\text { Pre-ART HIV-1 DNA } \\
\quad\left(\log _{10} \text { copies } / 10^{6} \text { PBMCs), median (IQR), }\right.\end{array}$ & $2.0(1.7-2.2)$ & $1.8(1.5-2.4)$ & $2.0(1.8-2.2)$ & 0.379 \\
\hline $\begin{array}{l}\text { Pre-ART plasma viral load } \\
\quad\left(\log _{10} \text { copies/mL), median (IQR) }\right.\end{array}$ & $4.1(3.6-4.5)$ & $4.0(3.6-4.4)$ & $4.2(3.7-4.6)$ & 0.445 \\
\hline Pre-ART CD4 ${ }^{+}$T-cell count (cells/ $\mu \mathrm{L}$ ), median (IQR) & $305(256-385)$ & $305(274-412)$ & $306(232-378)$ & 0.312 \\
\hline Nadir CD4 ${ }^{+}$T-cell count (cells/ $\left.\mu \mathrm{L}\right)$, median (IQR) & $292(245-357)$ & $295(271-374)$ & $291(224-350)$ & 0.240 \\
\hline Pre-ART CD8 ${ }^{+}$T-cell count (cells/ML), median (IQR) & $845(614-1073)$ & $859(634-1114)$ & $763(607-1074)$ & 0.907 \\
\hline Pre-ART CD4/CD8 ratio, median (IQR) & $0.35(0.27-0.51)$ & $0.42(0.29-0.51)$ & $0.34(0.24-0.49)$ & 0.180 \\
\hline $\begin{array}{l}\text { HIV-1 DNA after } 2 \text { years' ART } \\
\text { (log10 copies/10 } 10^{6} \text { PBMCs), median (IQR) }\end{array}$ & $1.7(1.3-2.0)$ & $1.3(1.3-1.3)$ & $1.9(1.6-2.4)$ & $<0.001$ \\
\hline
\end{tabular}



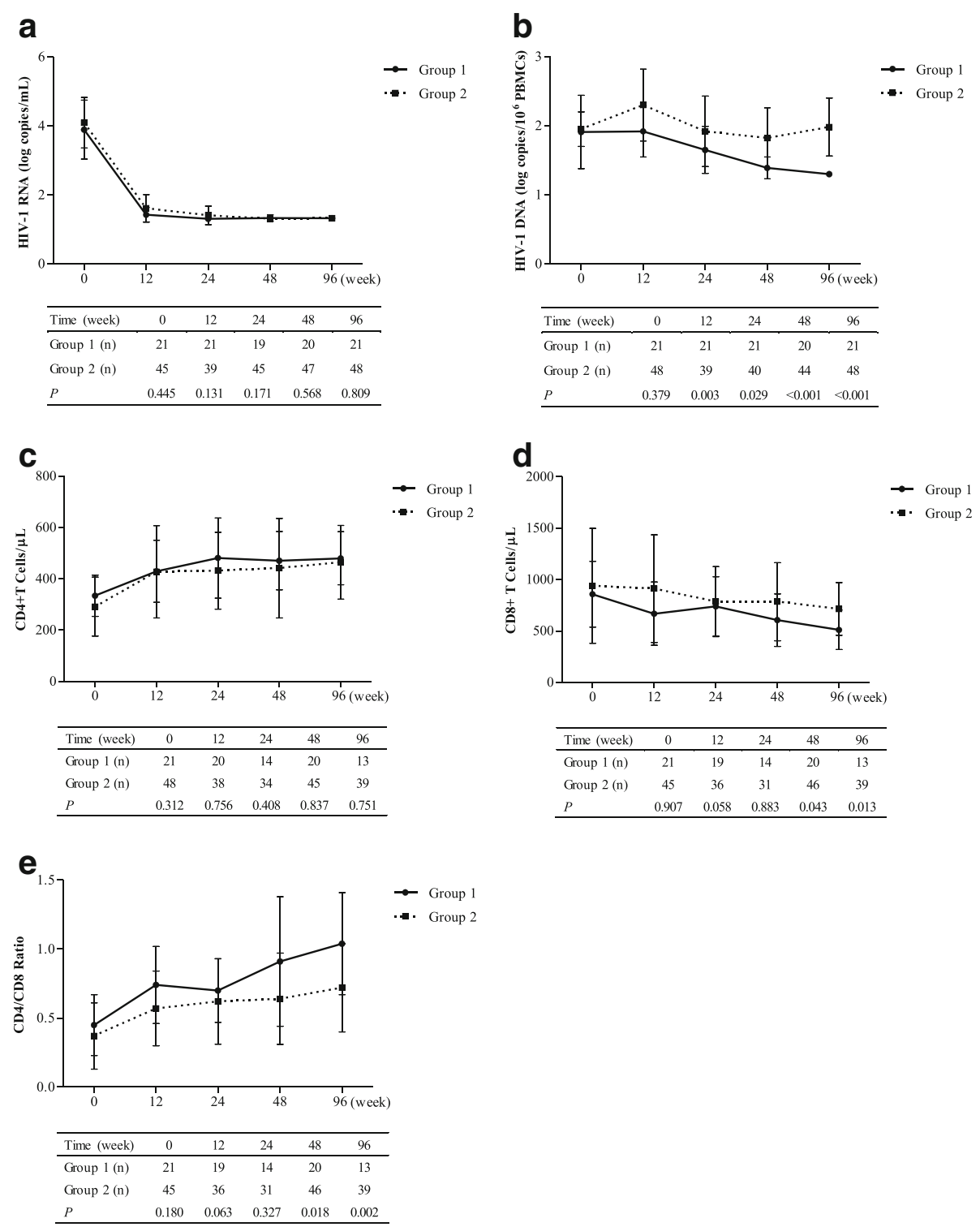

Fig. 1 Dynamic changes to cellular and viral parameters in HIV-1-infected patients during ART treatment. In these retrospective studies, the time-course parameters, including the viral load (a), HIV-1 DNA level (b), and peripheral $\mathrm{CD}^{+}(\mathbf{c})$ and $\mathrm{CD}^{+}$T-lymphocyte counts (d) from ATR-treated patients were recorded, and the CD4/CD8 ratio was calculated (e). $P<0.05$ is considered significant

binary logistic regression model was used for the analysis. Univariate logistic regression revealed that a lower $\mathrm{CD}^{+}$ T-cell count and a higher CD4/CD8 ratio at week 96 were beneficial factors associated with undetectable HIV-1 DNA levels at 96 weeks of ART in group $1(p=0.018$ and 0.014, respectively, Table 2). However, only the CD4/CD8 ratio at week 96 remained after multivariate logistic regression. Patients with a higher CD4/CD8 ratio were more likely to achieve ultralow HIV-1 DNA levels after 2 years of ART [per 0.1 increase, odds ratio $(\mathrm{OR})=1.29,95 \%$ confidence interval (CI), 1.05-1.59, $p=0.017$, Table 2].

In our study, all participants were virally suppressed (HIV-1 RNA $<50$ copies $/ \mathrm{mL}$ ) at week 96. Detectable low-level viremia at week $96(20-50 \mathrm{copies} / \mathrm{mL})$ was seen in 4 patients. To eliminate the effect of residual viremia on the level of HIV-1 DNA, we analyzed only patients with undetectable HIV-1 RNA. As before, the CD4/CD8 ratio at week 96 was the only factor associated with undetectable HIV-1 DNA at week $96(\mathrm{OR}=$ 1.26, 95\% CI, 1.04-1.53, $p=0.021$, Additional file 1: Table S1).

\section{Discussion}

This was a case control study of chronically HIV-1infected patients receiving ART for 2 years. Twenty-one patients had an HIV-1 DNA level lower than the 
Table 2 Factors associated with an ultralow HIV-1 DNA level (<20 copies/10 6 PBMCs) at week 96

\begin{tabular}{|c|c|c|c|c|c|c|}
\hline \multirow[t]{2}{*}{ Variables } & \multirow[b]{2}{*}{ OR } & \multicolumn{2}{|l|}{ Univariate } & \multirow[b]{2}{*}{ OR } & \multicolumn{2}{|l|}{ Multivariate } \\
\hline & & $95 \% \mathrm{Cl}$ & $P$ & & $95 \% \mathrm{Cl}$ & P \\
\hline Sex & & & 0.100 & & & 0.092 \\
\hline Male & 1.00 & & & 1.00 & & \\
\hline Female & 2.42 & $(0.85-6.93)$ & & 3.40 & $(0.82-14.15)$ & \\
\hline Age (years) & 1.01 & $(0.96-1.07)$ & 0.633 & & & \\
\hline Time from diagnosis to ART (months) & 0.98 & $(0.94-1.01)$ & 0.183 & & & \\
\hline Transmission route & & & 0.857 & & & \\
\hline Homosexual & 1.00 & & & & & \\
\hline Heterosexual & 1.36 & $(0.44-4.27)$ & & & & \\
\hline Others & 1.42 & $(0.20-9.82)$ & & & & \\
\hline HIV-1 subtype & & & 0.717 & & & \\
\hline$A E$ & 1.00 & & & & & \\
\hline$B / C / B C$ & 1.48 & $(0.37-5.96)$ & 0.584 & & & \\
\hline Others & 1.68 & $(0.48-5.95)$ & 0.418 & & & \\
\hline ART therapy & & & 0.477 & & & \\
\hline $\mathrm{AZT} / \mathrm{d} 4 \mathrm{~T}+3 \mathrm{TC}+\mathrm{NVP}$ & 1.00 & & & & & \\
\hline $\mathrm{TDF}+3 \mathrm{TC}+\mathrm{EFV}$ & 0.67 & $(0.22-2.04)$ & & & & \\
\hline Plasma viral load at enrollment (log copies/mL) & 0.71 & $(0.36-1.41)$ & 0.330 & & & \\
\hline HIV-1 DNA at enrollment (log copies/10 $10^{6}$ PBMCs) & 0.72 & $(0.17-3.11)$ & 0.656 & & & \\
\hline $\mathrm{CD}^{+} \mathrm{T}$-cell count at enrollment (cells/ $\left.\mu \mathrm{L}\right)$ & 1.00 & $(1.00-1.01)$ & 0.134 & & & \\
\hline Nadir CD4 ${ }^{+}$T-cell count (cells/ML) & 1.00 & $(1.00-1.01)$ & 0.129 & & & \\
\hline $\mathrm{CD}^{+} \mathrm{T}$-cell count at enrollment (cells/ $\left.\mu \mathrm{L}\right)$ & 1.00 & $(1.00-1.00)$ & 0.528 & & & \\
\hline CD4/CD8 ratio at enrollment & 1.19 & $(0.95-1.48)$ & 0.124 & & & \\
\hline Plasma viral load at week 96 & & & 0.808 & & & \\
\hline Undetectable & 1.00 & & & & & \\
\hline Viremia & 0.75 & $(0.07-7.66)$ & & & & \\
\hline $\mathrm{CD}^{+}$T-cell count at week 96 (cells $\left./ \mu \mathrm{L}\right)$ & 1.00 & $(1.00-1.00)$ & 0.709 & & & \\
\hline $\mathrm{CD}^{+}$T-cell count at week 96 (cells/ $\left.\mu \mathrm{L}\right)$ & 0.99 & $(0.99-0.99)^{a}$ & 0.018 & 1.00 & $(0.99-1.00)$ & 0.462 \\
\hline CD4/CD8 ratio at week 96 (per 0.1 increase) & 1.28 & $(1.05-1.55)$ & 0.014 & 1.29 & $(1.05-1.59)$ & 0.017 \\
\hline
\end{tabular}

OR Odds ratio, $\mathrm{Cl}$ confidence interval, ART Antiretroviral therapy, PBMCs Peripheral blood mononuclear cells a $0.993 \sim 0.999$

detection limit at week 96. After matching the two groups for baseline HIV-1 DNA levels, the CD4/CD8 ratio at week 96 was the only factor that was associated with an ultralow HIV-1 DNA level.

The most striking discovery of this study was that we found 21 patients who achieved an undetectable level of the HIV-1 DNA. The most important feature of this group of 21 patients was their relatively lower baseline HIV-1 DNA level (median, 1.8 log copies/ $10^{6}$ PBMCs, Table 1), which was significantly lower than that of the screened population (median 3.05 $\log$ copies $/ 10^{6}$ PBMCs; data not shown). A previous study showed that the HIV-1 DNA level following ART was strongly associated with the pre-ART HIV1 DNA level [14]. We focused on analyzing other factors associated with below-detection-level DNA by matching the baseline HIV-1 DNA level in the two groups.

During successful antiretroviral treatment, we observed no difference in viral inhibition or $\mathrm{CD} 4^{+} \mathrm{T}$-cell recovery between the two groups. Nevertheless, we found significant differences in the $\mathrm{CD} 8^{+} \mathrm{T}$-cell count and $\mathrm{CD} 4 / \mathrm{CD} 8$ ratio between the two groups at weeks 48 and $96 . \mathrm{CD}^{+} \mathrm{T}$ cells, which become elevated soon after infection and seldom normalize despite effective ART, are required for maintaining viral suppression and are independently associated with non-AIDS-related clinical events $[22,23]$. Our study showed that a reduction of the $\mathrm{CD}^{+}{ }^{-}$T-cell count was associated with an HIV-1 reservoir below the detection level. Moreover, the 
$\mathrm{CD} 4 / \mathrm{CD} 8$ ratio at week 96 was the only factor related to an ultralow HIV-1 DNA outcome. Chun et al. first revealed an inverse correlation between the CD4/CD8 ratio and frequency of $\mathrm{CD} 4^{+} \mathrm{T}$ cells carrying HIV-1 proviral DNA in infected individuals receiving ART [24]. Later, in 2012, this result was confirmed by Boulassel et al., who showed that the date of infection, duration of ART, and patient age did not influence the DNA level, in contrast to nadir $\mathrm{CD} 4^{+}$T-cell count and $\mathrm{CD} 4 / \mathrm{CD} 8$ ratio at baseline [12]. The nadir $\mathrm{CD}^{+}{ }^{+} \mathrm{T}$-cell count, however, did not influence the DNA outcome in our study. Recently, Rajesh and his colleagues applied a more ultrasensitive HIV-1 DNA detection assay and demonstrated that lower CD4/CD8 ratio was associated with persistently higher HIV-1 DNA during ART [25]. Our findings confirm and further extend these previous results.

For a long time, studies have placed intense focus on the inverse correlation between $\mathrm{CD} 4^{+} \mathrm{T}$ cells and the DNA reservoir [11-13]. In our study, we found no difference in the recovery of $\mathrm{CD} 4^{+} \mathrm{T}$ cells or the DNA reservoir. However, we found a sustained decrease in the number of $\mathrm{CD}^{+} \mathrm{T}$ cells in group 1 during ART, resulting in a continuous increase in the CD4/CD8 ratio, which has been considered a marker for immune activation and a parameter for disease progression for many years [26-28]. Patients with a lower CD4/CD8 ratio after long-term ART have a higher risk of non-AIDS-related morbidities and mortalities [28-31]. In fact, the relationship between the size of the HIV-1 DNA reservoir and level of immune activation has been observed in several studies, showing a positive association between the integrated HIV-1 DNA load and frequency of activated $\mathrm{CD}^{+}$or $\mathrm{CD}^{+}{ }^{+} \mathrm{T}$ cells $\left(\mathrm{HLA}-\mathrm{DR}^{+}, \mathrm{CD} 38^{+}, \mathrm{PD}-1^{+}\right.$) during consistently suppressive therapy $[16,17,32,33]$. The current opinion is that ART suppresses HIV-1 replication, resulting in progressive $\mathrm{CD} 4^{+} \mathrm{T}$-cell recovery but incomplete restoration of the $\mathrm{CD} 4 / \mathrm{CD} 8$ ratio. A low CD4/CD8 ratio indicates a high extent of immune activation and enhanced homeostatic proliferation of HIV-1-infected $\mathrm{CD}^{+} \mathrm{T}$ cells, resulting in the persistence and perpetuation of the DNA reservoir $[34,35]$.

There were some limitations to our study. In addition to the small sample size, the duration of ART in our study was not sufficient to fully understand the longterm effects of ART (or the CD4/CD8 ratio) on the HIV-1 DNA reservoir. However, the reservoir stayed stable after 1 to 2 years of ART. Furthermore, immune activation data such as the dynamic changes in HLA-DR and $\mathrm{CD} 38$ markers expressed on the surface of $\mathrm{CD} 4{ }^{+}$ and $\mathrm{CD} 8^{+} \mathrm{T}$ cells were lacking, and this information may help provide insight into the relationship between the CD4/CD8 ratio and HIV-1 DNA reservoir. In addition, we detected HIV-1 DNA only in peripheral blood, whereas larger HIV-1 reservoirs exist in gut-associated lymph tissues and lymph nodes [36, 37]. Whether an ultralow level of HIV-1 DNA can also be found in these structures remains unknown.

\section{Conclusions}

In conclusion, our study is the first to observe a belowdetection-level HIV-1 DNA reservoir in a small group of chronically HIV-1-infected patients after receiving ART for 2 years. After matching the HIV-1 DNA level of our two groups at baseline, CD4/CD8 ratio at week 96 was the only factor associated with an ultralow HIV-1 DNA outcome. Considering that a lower total HIV-1 DNA level and better immune status are meaningful factors for functional cure [38], our study may contribute to the monitoring of patients on ART who will be selected to participate in eradication studies. Our study suggests that in the management of HIV-1-infected patients, the recovery of $\mathrm{CD} 4 / \mathrm{CD} 8$ ratio should be given more attention. At the same time, combined use of immune modulators that can improve $\mathrm{CD}_{4}^{+}$T-cell recovery and decrease immune activation [39] may help achieve lower HIV-1 DNA levels.

\section{Additional file}

Additional file 1: Table S1. Factors associated with an ultralow HIV-1 DNA level (<20 copies/106 PBMCs) at week 96. Only patients with undetectable HIV-1 RNA at week 96 were analyzed. (DOCX 20 kb)

\section{Abbreviations}

ART: Antiretroviral therapy; Cl: Confidence interval; IQR: Inter-quartile range; OR: Odds ratio; PBMCs: Peripheral blood mononuclear cells

Acknowledgements

We thank all the subjects and staff in the original parent studies for their participation: Beijing You'an Hospital, Capital Medical University; Beijing Ditan Hospital, Capital Medical University; First Affiliated Hospital of China Medical University; Shanghai Public Health Clinical Center, Fudan University; First Affiliated Hospital of Zhejiang University School of Medicine; Fuzhou Infectious Diseases Hospital, Fujian Medical University; Guangzhou No. 8 People's Hospital; Shenzhen Third People's Hospital; Guangxi No. 4 People's Hospital; Guangxi Center for Disease Prevention and Control; and Guangxi Longtan Hospital.

\section{Funding}

Funding for this study was provided by the China National Key Technologies R\&D Program for the 13th Five-year Plan (2017ZX10202101-001) and CAMS Innovation Fund for Medical Sciences (CAMS-I2M-1-014). The funding source had no role in the study design, data collection, data analysis, preparation of the manuscript, or decision to publish.

\section{Availability of data and materials}

The datasets used and/or analyzed in the current study are available from the corresponding author on reasonable request.

\section{Authors' contributions}

Conceived and designed the experiments: TSL. Performed the experiments: YSY, NDW, YH, TZ, JX, ZFQ. Recruitment, compliance education, and follow-up of the patients: XJS, YLL and TSL. Collected the clinical data: YSY, NDW, XJS, and YLL. Analyzed the clinical data: YSY. Wrote the paper: YSY. Rigorously reviewed the manuscript: JPR, JHW and TSL. All authors participated in the manuscript review and approved the final version of the text as submitted to BMC Infectious Disease. 


\section{Ethics approval and consent to participate}

The Ethic Committee of Peking Union Medical College Hospital approved this study, and all participants provided written informed consent.

\section{Consent for publication}

Not applicable.

\section{Competing interests}

The authors declare that they have no competing interests to disclose.

\section{Publisher's Note}

Springer Nature remains neutral with regard to jurisdictional claims in published maps and institutional affiliations.

\begin{abstract}
Author details
'Department of Infectious Diseases, Peking Union Medical College Hospital, Chinese Academy of Medical Sciences \& Peking Union Medical College, Beijing 100730, China. ${ }^{2}$ Clinical Immunology Center, Chinese Academy of Medical Sciences, Beijing 100730, China. ${ }^{3}$ Center for AIDS Research, Chinese Academy of Medical Sciences and Peking Union Medical College, Beijing 100730, China. ${ }^{4}$ Division of Hematology \& Chronic Viral IIIness Service, McGill University Health Centre, Quebec, Canada. ${ }^{5}$ CAS Key Laboratory of Molecular Virology and Immunology, Institute Pasteur of Shanghai, Chinese Academy of Sciences, Shanghai 200031, China. ${ }^{6}$ University of Chinese Academy of Sciences, Beijing, China.
\end{abstract}

Received: 28 June 2017 Accepted: 28 November 2017

Published online: 15 December 2017

\section{References}

1. Deeks SG, Autran B, Berkhout B, Benkirane M, Cairns S, Chomont N, et al. Towards an HIV cure: a global scientific strategy. Nat Rev Immunol. 2012; 12(8):607-14.

2. Buzon MJ, Martin-Gayo E, Pereyra F, Ouyang Z, Sun H, Li JZ, et al. Long-term antiretroviral treatment initiated at primary HIV-1 infection affects the size, composition, and decay kinetics of the reservoir of HIV-1-infected CD4 T cells. J Virol. 2014;88(17):10056-65.

3. Wong JK, Hezareh M, Gunthard HF, Havlir DV, Ignacio CC, Spina CA, et al. Recovery of replication-competent HIV despite prolonged suppression of plasma viremia. Science. 1997;278(5341):1291-5.

4. Finzi D, Hermankova M, Pierson T, Carruth LM, Buck C, Chaisson RE, et al. Identification of a reservoir for HIV-1 in patients on highly active antiretroviral therapy. Science. 1997;278(5341):1295-300.

5. Chun TW, Stuyver L, Mizell SB, Ehler LA, Mican JA, Baseler M, et al. Presence of an inducible HIV-1 latent reservoir during highly active antiretroviral therapy. Proc Natl Acad Sci U S A. 1997;94(24):13193-7.

6. Barton K, Winckelmann A, Palmer S. HIV-1 reservoirs during suppressive therapy. Trends Microbiol. 2016:24(5):345-55.

7. Williams JP, Hurst J, Stohr W, Robinson N, Brown H, Fisher M, et al. HIV-1 DNA predicts disease progression and post-treatment virological control. elife. 2014;3:e03821.

8. Li JZ, Etemad B, Ahmed H, Aga E, Bosch RJ, Mellors JW, et al. The size of the expressed HIV reservoir predicts timing of viral rebound after treatment interruption. AIDS. 2016;30(3):343-53.

9. Rouzioux C, Hubert JB, Burgard M, Deveau C, Goujard C, Bary M, et al. Early levels of HIV-1 DNA in peripheral blood mononuclear cells are predictive of disease progression independently of HIV-1 RNA levels and CD4+ T cell counts. J Infect Dis. 2005;192(1):46-55.

10. Gianotti N, Canducci F, Galli L, Cossarini F, Salpietro S, Poli A, et al. HIV DNA loads, plasma residual viraemia and risk of virological rebound in heavily treated, virologically suppressed HIV-infected patients. Clin Microbiol Infect. 2015;21(1):103 e7- e10

11. Burgard M, Boufassa F, Viard JP, Garrigue I, Ruffault A, Izopet J, et al. Factors influencing peripheral blood mononuclear cell-associated HIV-1 DNA level after long-term suppressive antiretroviral therapy in 236 patients. AIDS. 2009;23(16):2165-71.

12. Boulassel MR, Chomont N, Pai NP, Gilmore N, Sekaly RP, Routy JP. CD4 T cell nadir independently predicts the magnitude of the HIV reservoir after prolonged suppressive antiretroviral therapy. J Clin Virol. 2012;53(1):29-32.

13. Watanabe D, Ibe S, Uehira T, Minami R, Sasakawa A, Yajima K, et al. Cellular HIV-1 DNA levels in patients receiving antiretroviral therapy strongly correlate with therapy initiation timing but not with therapy duration. BMC Infect Dis. 2011;11:146.

14. Hocqueloux L, Avettand-Fenoel V, Jacquot S, Prazuck T, Legac E, Melard A, et al. Long-term antiretroviral therapy initiated during primary HIV-1 infection is key to achieving both low HIV reservoirs and normal T cell counts. J Antimicrob Chemother. 2013;68(5):1169-78.

15. Sarmati L, Parisi SG, Nicastri E, d'Ettorre G, Palmisano L, Andreotti M, et al. Association between cellular human immunodeficiency virus DNA level and immunological parameters in patients with undetectable plasma viremia level during highly active antiretroviral therapy. J Clin Microbiol. 2005;43(12): $6183-5$

16. Hatano H, Jain V, Hunt PW, Lee TH, Sinclair E, Do TD, et al. Cell-based measures of viral persistence are associated with immune activation and programmed cell death protein 1 (PD-1)-expressing CD4+ T cells. J Infect Dis. 2013;208(1):50-6.

17. Ruggiero A, De Spiegelaere W, Cozzi-Lepri A, Kiselinova M, Pollakis G, Beloukas A, et al. During stably suppressive antiretroviral therapy integrated HIV-1 DNA load in peripheral blood is associated with the frequency of CD8 cells expressing HLA-DR/DP/DQ. EBioMedicine. 2015;2(9):1153-9.

18. Persaud D, Gay H, Ziemniak C, Chen YH, Piatak M Jr, Chun TW, et al. Absence of detectable HIV-1 viremia after treatment cessation in an infant. N Engl J Med. 2013;369(19):1828-35.

19. Saez-Cirion A, Bacchus C, Hocqueloux L, Avettand-Fenoel V, Girault I, Lecuroux C, et al. Post-treatment HIV-1 controllers with a long-term virological remission after the interruption of early initiated antiretroviral therapy ANRS VISCONTI study. PLoS Pathog. 2013;9(3):e1003211.

20. Li T, Guo F, Li Y, Zhang C, Han Y, Lye W, et al. An antiretroviral regimen containing 6 months of stavudine followed by long-term zidovudine for first-line HIV therapy is optimal in resource-limited settings: a prospective, multicenter study in China. Chin Med J. 2014;127(1):59-65.

21. Xie J, Han Y, Qiu Z, Li Y, Li Y, Song X, et al. Prevalence of hepatitis B and C viruses in HIV-positive patients in China: a cross-sectional study. J Int AIDS Soc. 2016;19(1):20659.

22. Cartwright EK, Spicer L, Smith SA, Lee D, Fast R, Paganini S, et al. CD8(+) lymphocytes are required for maintaining viral suppression in SIV-infected macaques treated with short-term antiretroviral therapy. Immunity. 2016; 45(3):656-68.

23. Cao W, Mehraj V, Kaufmann DE, Li T, Routy J-P. Elevation and persistence of CD8 T-cells in HIV infection: the Achilles heel in the ART era. J Int AIDS Soc. 2016;19(1)

24. Chun TW, Justement JS, Pandya P, Hallahan CW, McLaughlin M, Liu S, et al. Relationship between the size of the human immunodeficiency virus type 1 (HIV-1) reservoir in peripheral blood CD4+ T cells and CD4+:CD8+ T cell ratios in aviremic HIV-1-infected individuals receiving long-term highly active antiretroviral therapy. J Infect Dis. 2002;185(11):1672-6.

25. Gandhi RT, McMahon DK, Bosch RJ, Lalama CM, Cyktor JC, Macatangay BJ, et al. Levels of HIV-1 persistence on antiretroviral therapy are not associated with markers of inflammation or activation. PLoS Pathog. 2017;13(4): e1006285.

26. Taylor JM, Fahey JL, Detels R, Giorgi JV. CD4 percentage, CD4 number, and CD4:CD8 ratio in HIV infection: which to choose and how to use. J Acquir Immune Defic Syndr. 1989;2(2):114-24.

27. Serrano-Villar S, Gutierrez C, Vallejo A, Hernandez-Novoa B, Diaz L, Abad Fernandez M, et al. The CD4/CD8 ratio in HIV-infected subjects is independently associated with T-cell activation despite long-term viral suppression. J Inf Secur. 2013;66(1):57-66

28. Serrano-Villar S, Perez-Elias MJ, Dronda F, Casado JL, Moreno A, Royuela A, et al. Increased risk of serious non-AIDS-related events in HIV-infected subjects on antiretroviral therapy associated with a low CD4/CD8 ratio. PLoS One. 2014; 9(1):e85798.

29. Serrano-Villar S, Sainz T, Lee SA, Hunt PW, Sinclair E, Shacklett BL, et al. HIV-infected individuals with low CD4/CD8 ratio despite effective antiretroviral therapy exhibit altered T cell subsets, heightened CD8+ T cell activation, and increased risk of non-AIDS morbidity and mortality. PLoS Pathog. 2014;10(5): e1004078.

30. Mudd JC, Lederman MM. CD8 T cell persistence in treated HIV infection. Curr Opin HIV AIDS. 2014;9(5):500-5.

31. Mussini C, Lorenzini P, Cozzi-Lepri A, Lapadula G, Marchetti G, Nicastri E, et al. CD4/CD8 ratio normalisation and non-AIDS-related events in individuals with HIV who achieve viral load suppression with antiretroviral therapy: an observational cohort study. Lancet HIV. 2015;2(3):e98-106. 
32. Cockerham LR, Siliciano JD, Sinclair E, O'Doherty U, Palmer S, Yukl SA, et al. CD4+ and CD8+ T cell activation are associated with HIV DNA in resting CD4+ T cells. PLoS One. 2014;9(10):e110731.

33. Murray JM, Zaunders JJ, McBride KL, Xu Y, Bailey M, Suzuki K, et al. HIV DNA subspecies persist in both activated and resting memory CD4+ T cells during antiretroviral therapy. J Virol. 2014;88(6):3516-26.

34. Chomont N, El-Far M, Ancuta P, Trautmann L, Procopio FA, Yassine-Diab B, et al. HIV reservoir size and persistence are driven by T cell survival and homeostatic proliferation. Nat Med. 2009;15(8):893-900.

35. Barouch DH, Deeks SG. Immunologic strategies for HIV-1 remission and eradication. Science. 2014;345(6193):169-74.

36. North TW, Higgins J, Deere JD, Hayes TL, Villalobos A, Adamson L, et al. Viral sanctuaries during highly active antiretroviral therapy in a nonhuman primate model for AIDS. J Virol. 2010;84(6):2913-22.

37. Svicher V, Ceccherini-Silberstein F, Antinori A, Aquaro S, Perno CF, Understanding HIV. Compartments and reservoirs. Curr HIV/AIDS Rep. 2014;11(2):186-94.

38. Calin R, Hamimi C, Lambert-Niclot S, Carcelain G, Bellet J, Assoumou L, et al. Treatment interruption in chronically HIV-infected patients with an ultralow HIV reservoir. AIDS. 2016;30(5):761-9.

39. Li T, Xie J, Li Y, Routy JP, Li Y, Han Y, et al. Tripterygium wilfordii hook F extract in CART-treated HIV patients with poor immune response: a pilot study to assess its immunomodulatory effects and safety. HIV Clin Trials. 2015;16(2):49-56.

\section{Submit your next manuscript to BioMed Central and we will help you at every step:}

- We accept pre-submission inquiries

- Our selector tool helps you to find the most relevant journal

- We provide round the clock customer support

- Convenient online submission

- Thorough peer review

- Inclusion in PubMed and all major indexing services

- Maximum visibility for your research

Submit your manuscript at www.biomedcentral.com/submit

C) Biomed Central 